\title{
Designing the composition of road concrete with chemical additives
}

\author{
Tursoat Amirov", Xojiakmal Aripov, Bobomurod Qurbonov, Matchon Tuxtayev, and \\ Sukhrob Rakhmatov \\ Tashkent State Transport University, Tashkent, Uzbekistan
}

\begin{abstract}
The article selected local building materials that are suitable for use for road concrete structures. Based on these materials, the composition of road concrete was selected, and its physical and mechanical properties were determined. Based on the results obtained, recommendations for improving road concrete's physical and mechanical properties were developed.
\end{abstract}

\section{Introduction}

Increasing demands for reliability, serviceability, and durability of the pavement are caused by the growth capacity of vehicles and traffic on roads. Over the past decade, the automobile fleet of Uzbekistan has grown several times. According to road specialists and designers, the traffic intensity on some roads is $1.5-3$ times higher than allowed for this road category [1-6].

As shown by domestic and international experience, the increasing traffic requirements are most met by roads with cement-concrete coverings.

The cement-concrete coating works in conditions of a complex stress state under the influence of repeated loads from cars and variable temperature and humidity fields. In addition, conglomerate materials such as cement concrete are characterized by internal stresses due to the heterogeneity of their structure and constantly occurring processes of structure formation and destruction. Increasing the resistance of road concrete to operational impacts is directly related to improving its physical and mechanical properties and structure.

This requires the study of ways to increase its operational reliability by designing the composition of concrete used for cement concrete pavements. Therefore, it is important to research the physical and mechanical properties of cement concrete.

Many scientists have studied the composition of heavy concrete in the country and abroad. Abroad, the physical and mechanical properties of guide heavy concrete S.V. Shestoperov, V. Rayxel, D. Konrad, L. I. Dvorkin, O. L. Dvorkin, S. Ramachandran, R. F. Feldman, E.Kh. Aminov and others have studied in Uzbekistan E.H. Aminov, M.M. Selimov E.Qosimov, Odilxo'jaev A.E, N. Samigov, B.B. Khasanov, and other scientists [2$18]$.

\footnotetext{
*Corresponding author: tursoat.amirov@mail.ru
} 
Requirements for cement concrete pavements currently under construction in Uzbekistan are given in Table 1. Russian scientist A.M. From the results of many years of study of the conditions of monolithic cement pavements of roads and airfields of Shane, it can be concluded that the long-term durability of the pavement is ensured if the requirements set out in Table 1 are met.

Table 1. Basic requirements for road cement concrete [8-12]

\begin{tabular}{|c|c|c|}
\hline № & Naming of indicators & The value of indicators \\
\hline 1 & Class on the compressive strength of concrete & At least V30 \\
\hline 2 & Class on the tensile strength of concrete & At least Btb 4.0 \\
\hline 3 & Mark of frost resistance of concrete & $\begin{array}{l}\text { F100 and higher (when tested according to } \\
\text { the 2nd basic method GOST 10060-2012) }\end{array}$ \\
\hline 4 & Fixed water-cement ratio & At most 0.45 \\
\hline 5 & $\begin{array}{l}\text { Cement allowed for the preparation of } \\
\text { concrete mixes }\end{array}$ & $\begin{array}{l}\text { Portland cement, mineralogical composition } \\
\text { is normalized }\end{array}$ \\
\hline 6 & $\begin{array}{l}\text { Quality of cement used (GOST } 10178 \text { for road } \\
\text { surfaces) }\end{array}$ & $\begin{array}{c}\text { Hardening - at least } 2 \text { hours, without signs of } \\
\text { false solidification, without technological } \\
\text { additives. }\end{array}$ \\
\hline 7 & \begin{tabular}{|c|} 
Quality of fillers \\
\end{tabular} & According to GOST 26633-2012 \\
\hline 8 & $\begin{array}{c}\text { Presence of plasticizer chemical compounds in } \\
\text { concrete mix }\end{array}$ & Condition according to GOST 26633-2012 \\
\hline 9 & $\begin{array}{l}\text { The presence of air-absorbing and gas- } \\
\text { forming compounds in the concrete mix }\end{array}$ & Condition according to GOST 26633-2012 \\
\hline 10 & $\begin{array}{l}\text { Volume of air absorbed into the concrete } \\
\text { mix, } \%\end{array}$ & $\begin{array}{c}6 \pm 1 \text { (according to GOST } 26633 \text { and GOST } \\
7473 \text {, at the place of laying the concrete } \\
\text { mix) }\end{array}$ \\
\hline 11 & $\begin{array}{c}\text { Porosity of concrete, } \% \\
\text { - open capillaries; } \\
\text {-conditionally closed } \\
\end{array}$ & $\begin{array}{c}\text { According to GOST } 12730.4 \\
- \text { no more than } 10-15 \\
- \text { at least } 3-7 \\
\end{array}$ \\
\hline 12 & $\begin{array}{l}\text { Recommended convenient location of } \\
\text { concrete mix }\end{array}$ & Marks P1 $(1-4 \mathrm{~cm})$ and $\mathrm{J} 1(\mathrm{sec})$ (at the bed) \\
\hline 13 & Maintenance of freshly laid concrete & $\begin{array}{l}\text { Using film-forming materials according to } \\
\text { SHNQ 3.06.03-08 }\end{array}$ \\
\hline
\end{tabular}

For the long-term performance of road concretes, concrete composition design methods should be used. This article is devoted to the issue of obtaining heavy concrete for road paving through the use of chemical compounds. This has a targeted effect on the process of structure formation in concrete, effectively resisting the effects of operational and climatic factors. With this method, the traditional principles of road concrete design will be followed.

For the long-term quality operation of the cement concrete pavement, the factors affecting the concrete must be taken into account during the design process (Figure 1).

Factors providing long-term durability of cement concrete coatings [1]. 


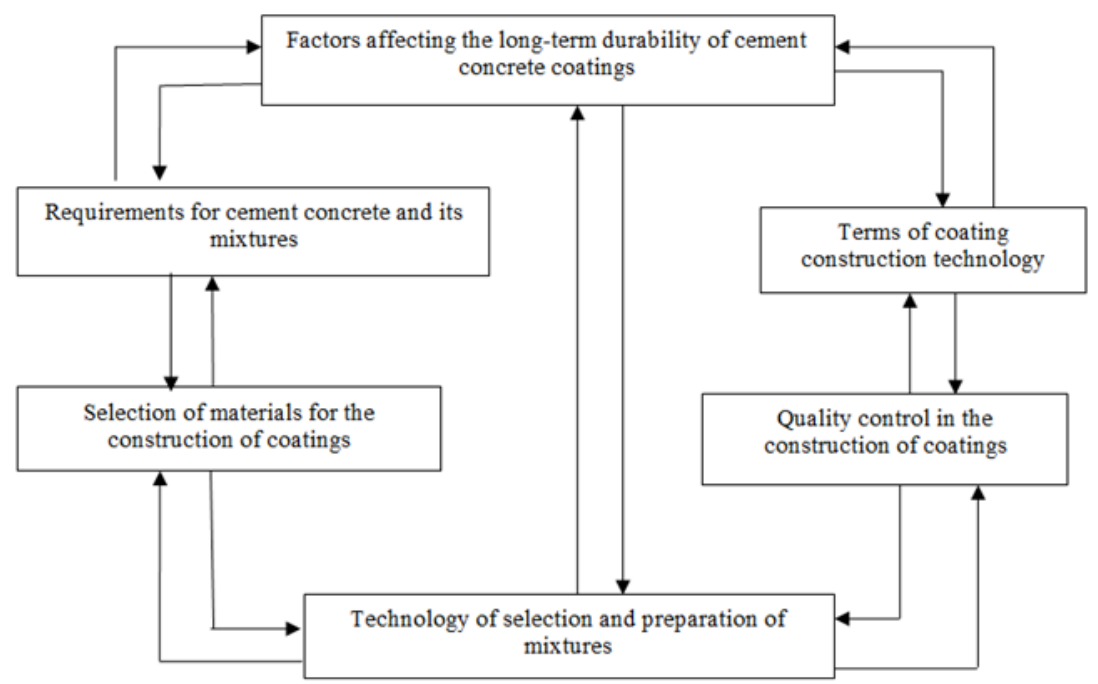

Fig. 1. Correlation of factors ensuring long-term durability of cement concrete coatings (interaction with arrows)

The strength, durability, and other properties of cement concrete depend on the quality of the local materials used. It is, therefore, important that we choose these materials wisely (Figure 2).

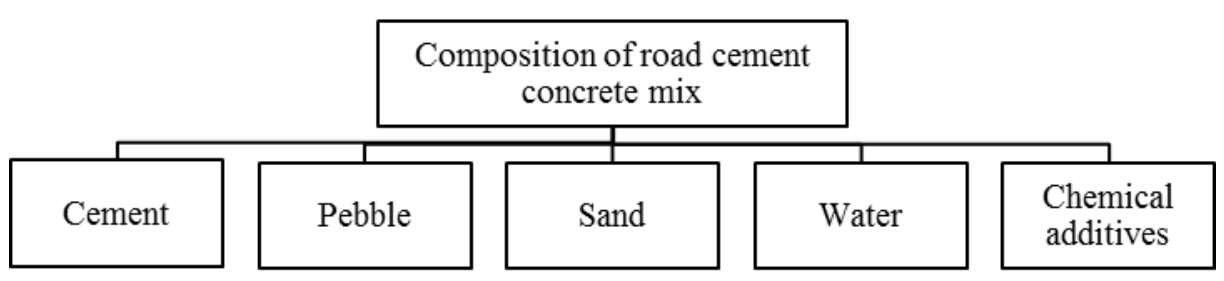

Fig. 2. Schematic view of the composition of the cement concrete mix

\section{The materials and methods of research}

We selected the concrete composition following GOST 27006. The materials selected for the concrete structure must be local but must also meet the standard requirements imposed on them for use in the concrete structure. This requires determining the properties of the materials we choose for the nominal composition of the concrete.

A binder in the mixture was used 400 sulphate-resistant Portland cement SSPS-400 D0, produced at the local plant "Kyzylkumtsement."

Some of the identified properties and mineralogical composition of Portland cement are shown in Table 2. 
Table 2. Test results of M-400 sulfate-resistant Portland cement

\begin{tabular}{|c|c|c|}
\hline Identified indicators & $\begin{array}{c}\text { Requirements of } \\
\text { GOST 22266-94 }\end{array}$ & $\begin{array}{c}\text { The results } \\
\text { obtained }\end{array}$ \\
\hline Compressive strength of a 28-day sample, MPa & 39.2 & 40.3 \\
\hline $\begin{array}{c}\text { Freezing time: } \\
\text { beginning } \\
\text { finish }\end{array}$ & $\begin{array}{c}\text { At least 45 min } \\
\text { 10 hours with excess }\end{array}$ & $\begin{array}{c}2 \text { hours } 15 \text { min } \\
4 \text { hours } 25 \text { min }\end{array}$ \\
\hline Fine content (№008 sieve residue), in\% & 15 each & 10 \\
\hline SO3 content,\% & With a surplus of 3.0 & 2.0 \\
\hline Amount of chloride ions Cl,\% & With a surplus of 0.1 & 0.06 \\
\hline Clinker composition, by weight \% yes \\
\hline Aluminum oxide (Al2O3) & With a surplus of 5.0 & 4.78 \\
\hline Magnesium oxide (MgO) & With a surplus of 5.0 & 2.28 \\
\hline Tri-calcium silicate (3CaO SiO2) & With more than 50 & 49.78 \\
\hline Tri Calcium Aluminate (3CaO Al2O3) & With a surplus of 5.0 & 3.59 \\
\hline $\begin{array}{c}\text { The sum of three calcium aluminates (3CaO } \\
\text { A12O3) and four calcium aluminaferrites (4CaO } \\
\text { Al2O3 Fe2O3) }\end{array}$ & With a surplus of 22.0 & 19.85 \\
\hline
\end{tabular}

Drinking water was used to prepare the concrete mix.

Juma quarry sand in Samarkand oblast was obtained as a fine aggregate, and its main properties were determined (Table 3).

Table 3. Properties of sand

\begin{tabular}{|c|c|c|c|}
\hline \multirow{2}{*}{$№$} & $\begin{array}{c}\text { The name of the detected } \\
\text { indicators }\end{array}$ & Normative requirement & Test results \\
\hline 1 & Bulk density, $\mathrm{kg} / \mathrm{m} 3$ & - & 1470 \\
\hline & Grain content, $\%$ & & \\
\cline { 2 - 4 } 2 & $-10 \mathrm{~mm}$ and larger & 0.5 each & 0.81 \\
\cline { 2 - 4 } & $-5 \mathrm{~mm}$ and larger & 10 each & 5.52 \\
\cline { 2 - 4 } & $-0.16 \mathrm{~mm}$ and smaller & 20 each & 12.08 \\
\hline \multirow{2}{*}{3} & $\begin{array}{c}0.63 \mathrm{~mm} \text { total residue } \\
\text { remaining in the sieve, } \%\end{array}$ & 53,16 \\
\hline 4 & The modulus of magnitude & $2.5-3.0$ & 2.6 \\
\hline 5 & Dust content, $\%$ & Not bolee 3.0 & 2.4 \\
\hline 6 & Amount of muddy grains, $\%$ & Not more than 0.5 & - \\
\hline 7 & Humidity, $\%$ & - & 8.1 \\
\hline
\end{tabular}

For the preparation of heavy concrete, we used Ziyadin quarry gravel of 5-20 $\mathrm{mm}$ and 20-40 $\mathrm{mm}$ as a large filler (Table 4 and Figure 3). 
Table 4. Determined indicators of Ziyadin's career

\begin{tabular}{|c|c|c|c|}
\hline № & The name of the detected indicators & $\begin{array}{c}\text { GOST } \\
\text { requirements }\end{array}$ & Test result \\
\hline 1 & Bulk density, $\mathrm{kg} / \mathrm{m} 3$ & - & \\
\hline 3 & Amount of crushed grains, $\%$ & At least 80 & 100 \\
\hline 4 & Quantity of coniferous and coniferous grains, $\%$ & $15-25$ & 19.1 \\
\hline 5 & Dust content, up to $\%$ & Not bolee 1.0 & 0.45 \\
\hline 6 & Amount of muddy grains, $\%$ & Not bolee & No. \\
\hline 7 & Amount of weak grains, $\%$ & 10 each & 2.54 \\
\hline 8 & Stability mark on fracture & At least 1200 & 1400 \\
\hline
\end{tabular}

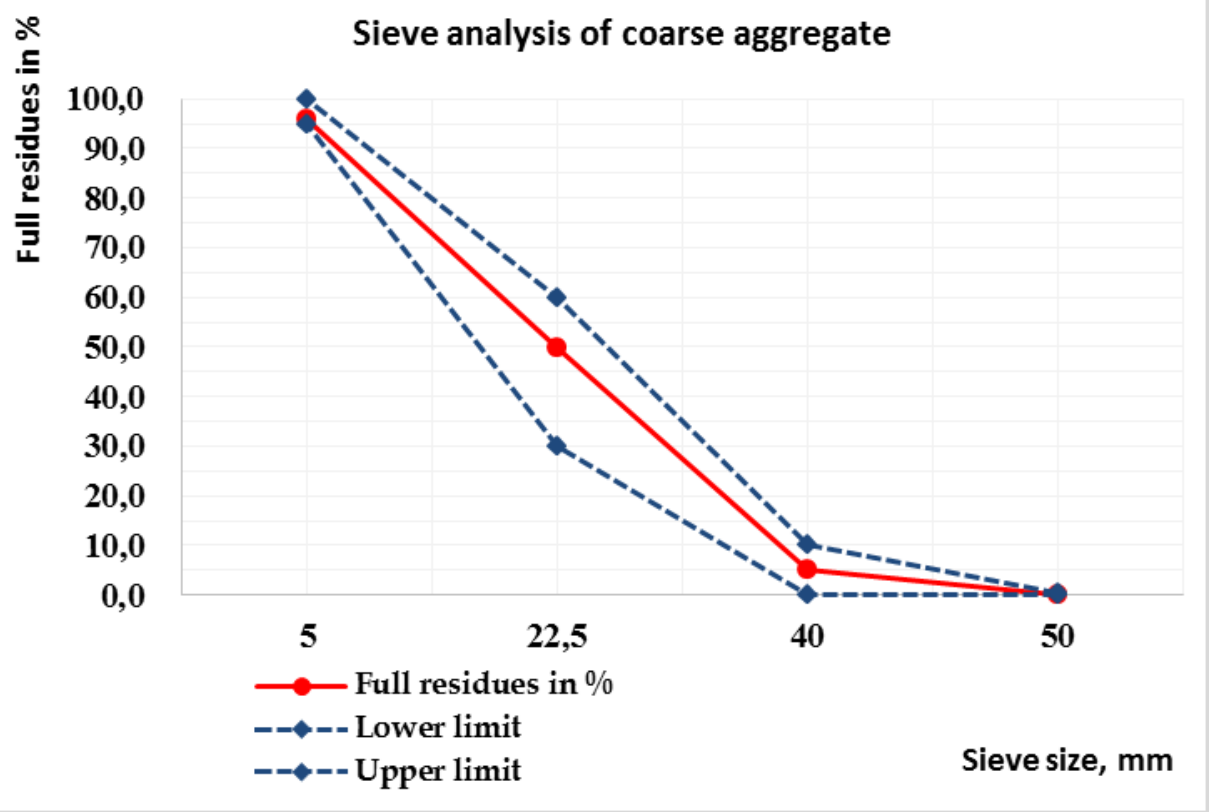

Fig. 3. The granular composition of the gravel

BASF plasticizer and air extractor compounds were used as chemical compounds (Table 5).

Table 5. Description of a chemical compound

\begin{tabular}{|c|c|}
\hline \multicolumn{2}{|c|}{ Chemical compound } \\
\hline Material requirements & GOST 24211-2008 TP PK №1202 (ASTMC 494-13) \\
\hline Density at a temperature of 200 C. & $1,030.02 \mathrm{~g} / \mathrm{cm} 3 \pm$ \\
\hline The recommended dose & $0.4 \%$ of the cement mass \\
\hline
\end{tabular}




\section{Results and Discussion}

Now the concrete mix composition has been designed using the above standard.

According to the selected composition, the consumption of materials for the preparation of concrete mix is given in Table 6 .

Table 6. Consumption of materials for the preparation of concrete mix

\begin{tabular}{|c|c|c|c|c|c|c|}
\hline $\begin{array}{l}\text { The serial } \\
\text { number of the }\end{array}$ & $\begin{array}{c}\text { Convenient } \\
\text { placement of the }\end{array}$ & \multirow{2}{*}{\multicolumn{2}{|c|}{ Name of materials }} & \multicolumn{3}{|c|}{$\begin{array}{l}\text { Consumption of materials } \\
\text { for } 1 \mathrm{~m} 3 \text { of concrete }\end{array}$} \\
\hline \multirow{8}{*}{ V-1 Concrete } & \multirow{8}{*}{$\begin{array}{c}\mathrm{P} 1 \\
(1-4 \mathrm{~cm})\end{array}$} & & & $\begin{array}{l}\text { Weigh } \\
\text { t, kg }\end{array}$ & $\begin{array}{l}\text { Densit } \\
\mathrm{y}, \mathrm{kg} / \\
\mathrm{dm} 3\end{array}$ & $\begin{array}{l}\text { Size, } \\
\text { dm3 }\end{array}$ \\
\hline & & \multicolumn{2}{|c|}{ Cement } & 400 & 3.11 & 128.6 \\
\hline & & \multicolumn{2}{|c|}{ Sand } & 694 & 2.65 & 261.9 \\
\hline & & \multicolumn{2}{|c|}{ Pebbles 5-20 mm } & 592 & 2.74 & 216.1 \\
\hline & & \multicolumn{2}{|c|}{ Pebbles $20-40 \mathrm{~mm}$} & 485 & 2.74 & 177.0 \\
\hline & & \multirow{2}{*}{$\begin{array}{l}\text { Chemical } \\
\text { compound } \\
\text { s }\end{array}$} & $\begin{array}{l}\text { Woerment BV } \\
25\end{array}$ & 1.60 & 1.03 & 1.55 \\
\hline & & & Micro Air 102 & 1.60 & 1.05 & 1.52 \\
\hline & & \multicolumn{2}{|r|}{ Water } & 156 & 1.0 & 156 \\
\hline
\end{tabular}

The main properties of heavy concrete, the composition of which is selected Determined following GOST 7473-2010 (Figure 4).
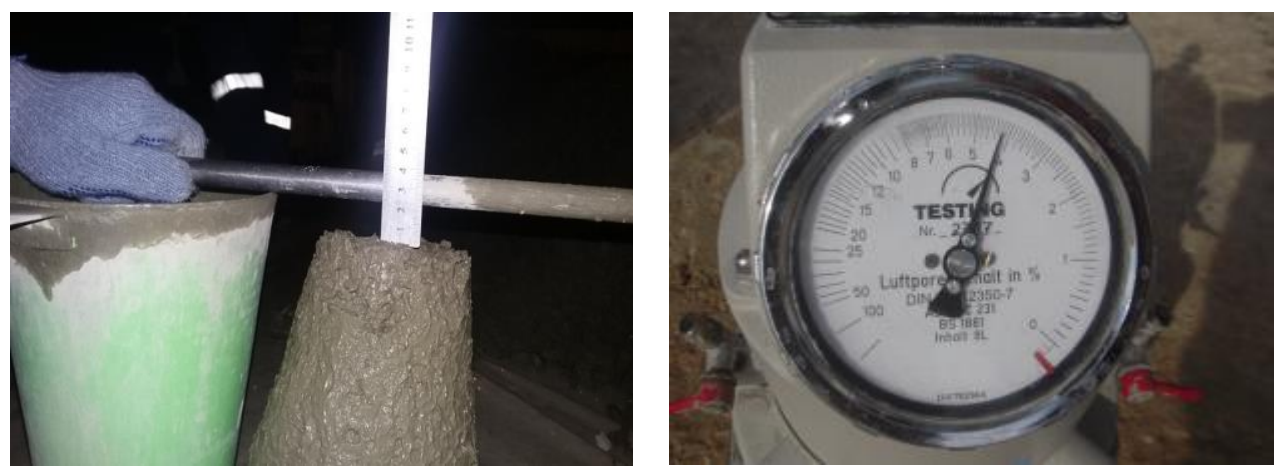

Fig. 4. The process of determining the basic properties of cement concrete mix

Another identified property of the cement concrete mix is the volume of air absorbed. This property leads to an increase in the cold resistance of concrete. Given that road concrete operates mainly in changing weather conditions, it is necessary to determine the volume of absorbed air in the concrete and ensure that its cold resistance does not fall below the guaranteed value.

After that, concrete samples were prepared in molds that meet the requirements of GOST 22685 and passed metrological inspection (Figure 5). 

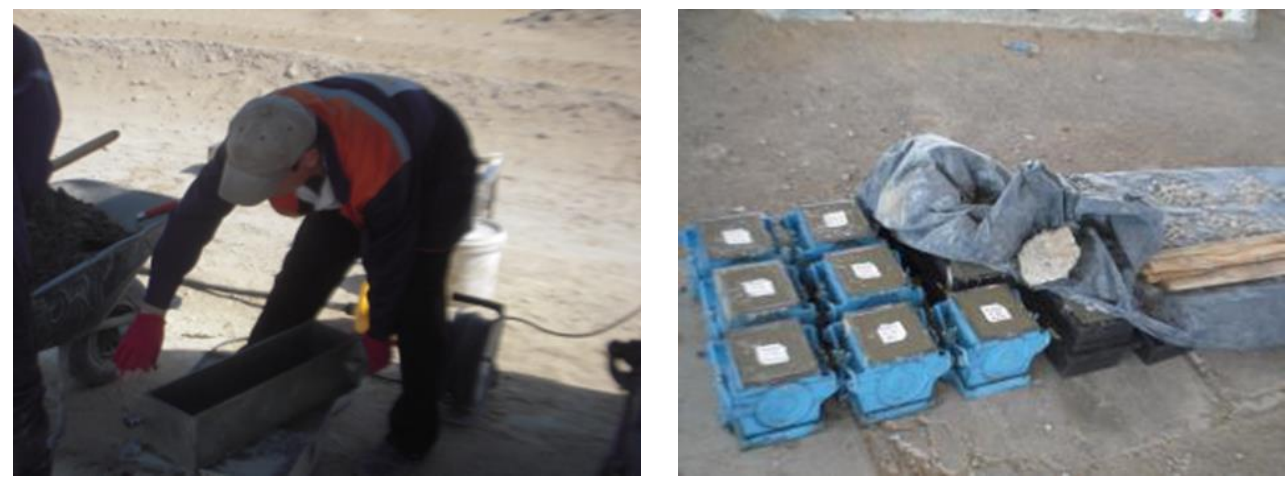

Fig. 5 The process of preparing control samples

As shown in Table 1, one of the main normative parameters of road concrete is its strength (Figure 6).
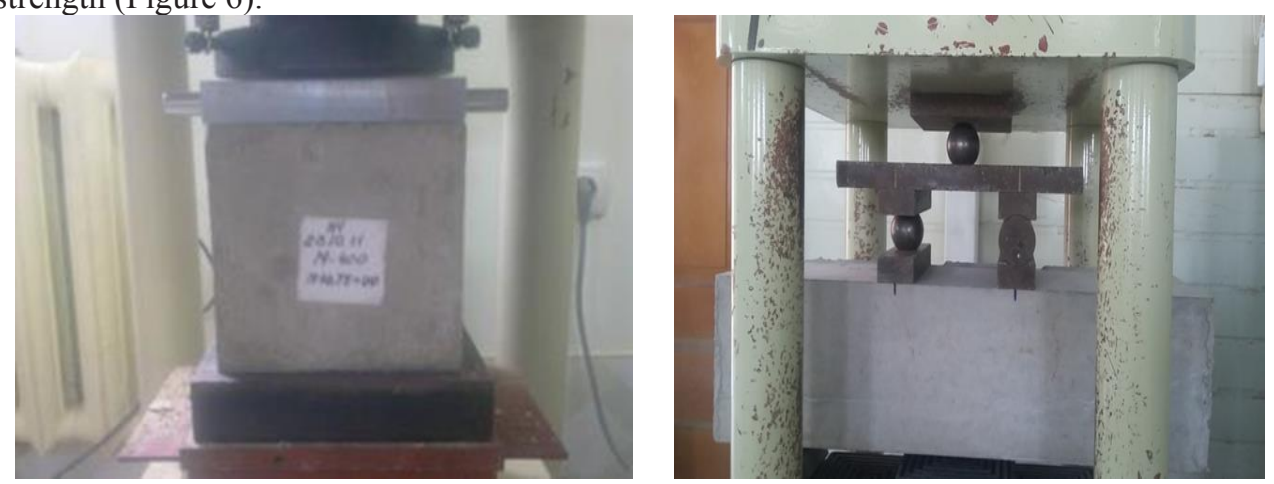

Fig. 6. The process of determining the compressive and flexural strength of cement concrete

The top layer of the highway should work mainly on bending. When M400 brand cement was used as a binder in cement concrete, the strength of this concrete from bending to elongation led to a change in the design age. Therefore, we determined the design age in terms of bending elongation strength of concrete designed based on local materials (Figure 7).

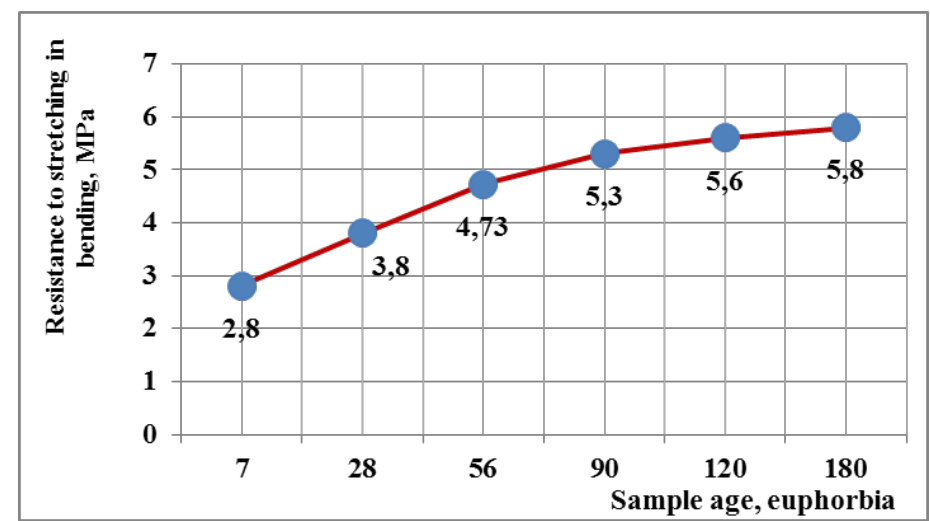

Fig. 7. The dependence of the tensile strength of cement concrete on the design age

As far as we know, road concrete has to work in more difficult conditions than other concrete structures. The reason is that the road structures are laid across the open area. This 
means that the concrete must be able to perform in hot conditions as well as in cold periods of the day.

The greater the volume of air is absorbed in the cement concrete, the greater the frost resistance of the cement concrete. Therefore along with its resistance to bending, elongation decreases. This requires the provision of strength indicators in selecting the volume of inhaled air in the cement concrete and frost resistance. This requires the determination of the volume of air inhaled, which provides an indicator of the strength and cold resistance.

Therefore, consider the relationship between the volume of air absorbed and the tensile strength of cement concrete (Figure 8).

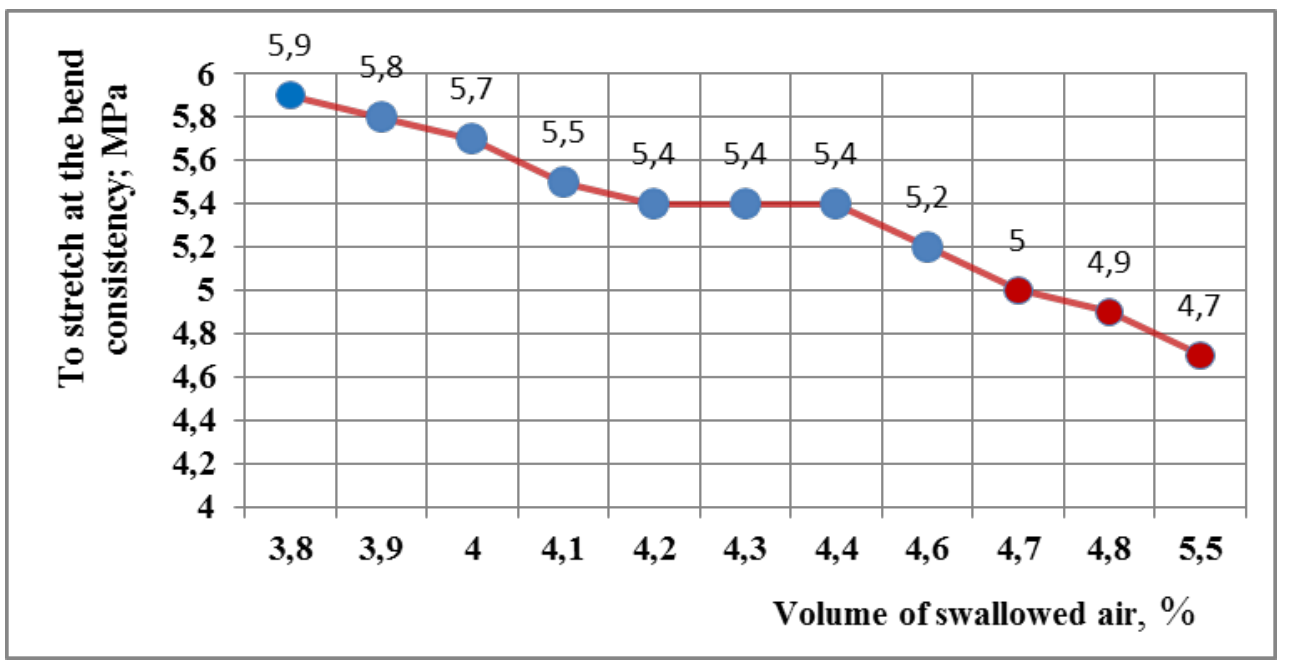

Fig. 8. Graph of the bending elongation strength of cement concrete as a function of the air volume is absorbed in the concrete mix.

When 400 grade cement is used as a binder in the cement concrete mix, it also affects its compressive strength. That is, it leads to a change in the design age of the cement concrete in terms of compressive strength. This can be verified by the compressive strength of cement concrete prepared with the addition of M400 brand cement by considering the results of laboratory tests of cement concrete samples at different ages (Figure 9).

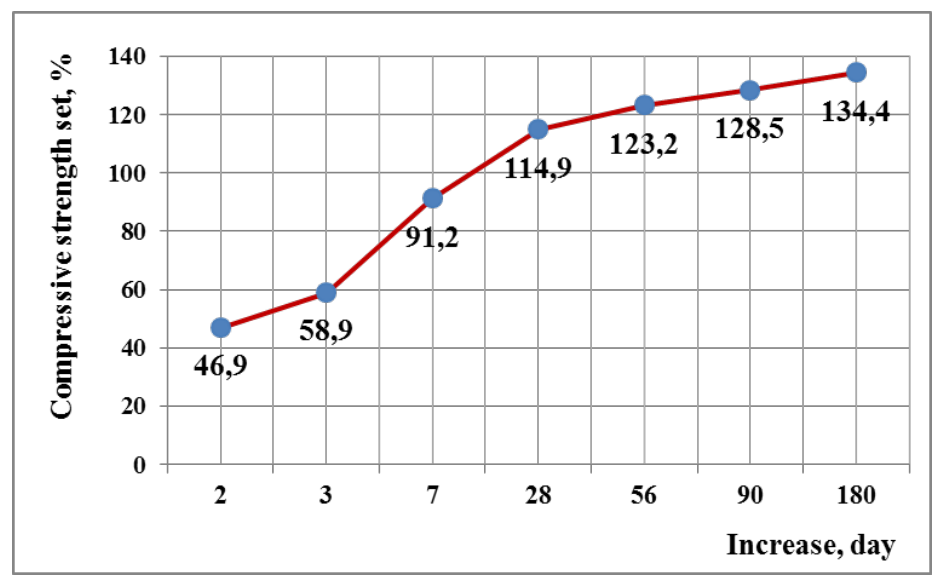

Fig. 9. Graph set of prochnosti betonnyx obraztsov 
The volume of absorbed air in the cement concrete mix also affects the compressive strength of the cement concrete. It is known that the more porous the cement concrete, the lower its load-bearing capacity. Hence the cement concrete mix the effect of the volume of absorbed air in the composition on the compressive strength of cement concrete was determined. Therefore, we consider that the volume of absorbed air in the cement concrete depends on the compressive strength indicators (Figure 10).

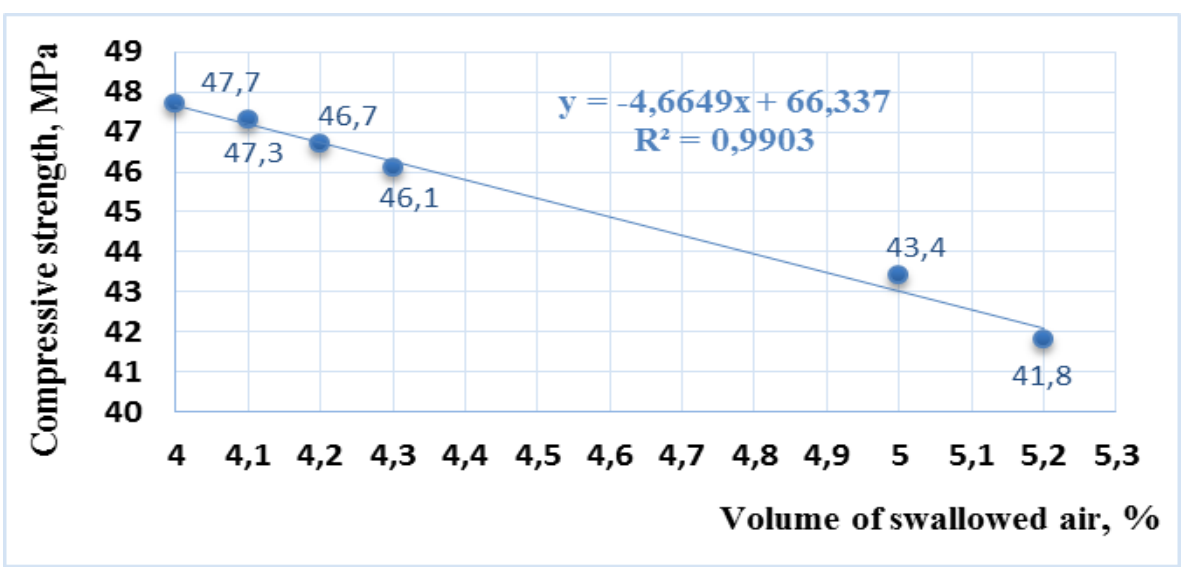

Fig. 10. Graph of the compressive strength of cement concrete samples as a function of the volume of air drawn into the cement concrete mix

The convenient location of cement concrete affects many of its properties. "The preparation of the cement mix should take into account the duration of its transportation from the cement plant to the concreting site, to ensure the required volume of inhaled air." Accordingly, to increase the durability of cement concrete and structures made of it, the choice of cement concrete composition used for road construction is determined by the need to obtain both the plastic properties of the cement concrete mix and the volume of absorbed air. Following GOST 26633-2012, to increase the quality and efficiency of cement concrete, it is necessary to add additives to the cement concrete mix.

\section{Conclusions}

It seems that it is possible to increase the resistance of the pavement to operational and climatic factors by improving (modifying) the structure of heavy concrete used for monolithic cement concrete pavements. To do this, the following work has been done in this article:

1. The composition of heavy concrete mix with guaranteed strength V30 (Btb 4.0) and higher class for road surface was designed based on M400 sulfate-resistant portland cement using chemical additives;

2. The possibility of obtaining quality concrete for intensive operation conditions was substantiated;

3. The optimal composition and physical and mechanical properties of heavy concrete based on chemical compounds that meet the required mechanical and operational properties were determined.

4. It can be seen from the projected composition of the concrete mix that if about 2250 $\mathrm{m} 3$ of concrete mix is used to build a cement concrete pavement with a width of $9.0 \mathrm{~m}$, a length of $1 \mathrm{~km}$, and a thickness of $25 \mathrm{~cm}$. Approximately 900 tons of Portland cement, 1560 tons of sand, and 2423 tons of gravel will be needed to prepare this amount of mixture. 


\section{References}

1. Amirov T.C. Highways and airfields build cement concrete pavements. Training manual-T.: "SANA STANDARD", p. 256, (2017)

2. Adilkhodjaev A., Hasanov B., Shaumarov S., Kondrashchenko V. Aerated concrete with predetermined pore parameters for the exterior walls of energy efficient buildings, IOP Conference Series: Materials Science and Engineering, 1030(1), 012006, (2021)

3. Khasanov B., Vatin N., Mirzaev T., Suyunov A., Radjabov M. Analysis of the mode of squeezing out excess water for mixing concrete mixture in the process of peristaltic compaction, IOP Conference Series: Materials Science and Engineering, 1030(1), 01202, (12021)

4. Khasanov B., Vatin N., Mirzaev T., Suyunov A., Radjabov M. Physicochemical fundamentals of modifying concrete mix and concrete, IOP Conference Series: Materials Science and Engineering, 1030(1), 012022, (2021)

5. Khasanov B., Vatin N., Ismailova Z., Mirzaev T. Physical modification of concrete mix and concrete, IOP Conference Series: Materials Science and Engineering, 883(1), 012205, (2020)

6. Khasanov B., Irmuhamedova L., Firlina G., Mirzaev T. Theoretical foundations of the structure formation of cement stone and concrete, IOP Conference Series: Materials Science and Engineering, 869(3), 032032, (2020)

7. Aminov E.KH. Klimat i beton. Tashkent,p.183, (1988)

8. Sodikov I. S. Features of the construction of cement-concrete coatings and prospects for development. Materials of the scientific-practical conference" actual problems of the automobile and road transport of Uzbekistan", pp. 4-21, Tashkent-2012.

9. Selimov M. M. Research of physical and mechanical properties and durability of cement concrete of flat monolithic structures in conditions of dry and hot climate: abstract of the dissertation of the Candidate of technical Sciences, p. 26. Tashkent, (1971)

10. Khalmukhamedov S. I. Research of new ways of care of concrete of road and airfield coverings in the conditions of dry and hot climate, p. 24, Tashkent, (1969)

11. Sheinin A.M. Cementobeton for road and airfield coverings, Transport, p. 151 (1991)

12. Shestoperov S.V. Quality control of concrete of transport structures. Moscow: Transport, p. 248, (1975)

13. SHNQ 2.05.02-07 « Automobile roads».

14. SHNQ 3.06.03-08 « Automobile roads».

15. GOST 26633-2012" heavy and fine-particle concrete. Technical conditions"

16. GOST 7473-2010" concrete mixtures. Technical conditions".

17. AASHTO «Standard specifications for transportation materials and methods of sampling and testing». Thirtieth Edition (2010)

18. European Standard EN 206-1:2000 «Concrete - Part 1: Specification, performance, production and conformity», (2000) 